\title{
Comparison between a microdiffusion and an ion exchange method for the determination of plasma ammonium
}

\author{
J. D. ACLAND ${ }^{1}$ AND R. STRONG \\ From the Department of Chemical Pathology, Sheffield University, Sheffield
}

SYNOPSIS The results of plasma-ammonium determinations by an ion-exchange method and by a microdiffusion method were compared on the same specimens with each other and with ammonium determinations carried out on the corresponding whole-blood specimens by the microdiffusion method. The plasma-ammonium levels of whole-blood specimens were higher than those of the corresponding plasma specimens, but the difference was not constant. Recoveries of added $\mathrm{NH}_{4}$ from plasma by the microdiffusion method ranged from 65 to $144 \%$. Recoveries of $\mathrm{NH}_{4}$ from the same specimens by the ion-exchange method ranged from 93 to $96 \%$. Of the two, the ion-exchange method was the only one of value.

Studies on venous plasma-ammonium levels in cardiac disorders have been reported (Acland and Strong, $1965 ; 1966)$ in which plasma ammonium was determined by the ion-exchange technique of Fenton (1962) slightly modified (Fenton and Williams, 1968). Plasma-ammonium levels ranging from 13.5 to $49.5 \mu \mathrm{g}$. of ammonium nitrogen per $100 \mathrm{ml}$. were recorded in a group of normal subjects and patients in whom there was no reason to suspect the presence of hepatic or respiratory disease. Somewhat higher normal ranges for the venous plasma ammonium level, determined after microdiffusion (Seligson and Seligson, 1951; Seligson and Hirahara, 1957), have been reported by Bessman and Evans (1955), by Conn (1960), and by Humoller, Barak, and Holthaus (1964). The difference between the normal ranges of plasma ammonium determined by the two methods has been attributed to the formation of ammonia from other nitrogenous constituents of plasma in the highly alkaline conditions used in the microdiffusion step (Dienst, 1961).

The normal range for the ammonium level of whole blood has been reported to be higher than that of plasma by Humoller et al. (1964) who used a microdiffusion technique. They also obtained evidence which suggested that the different ranges for plasma and whole blood resulted from $p \mathrm{H}$ differences between cells and plasma.

${ }^{1}$ Present address: Pathology Department, Central Middlesex Hospital, Park Royal, London, N.W.10.

Received for publication 17 March 1967.
The object of the present investigation was to find out whether there was a consistent difference (1) between plasma-ammonium levels determined after microdiffusion and after ion exchange, and (2) between whole-blood ammonium and plasma ammonium determined after microdiffusion. If these differences were consistent, the results of ammonium determinations on different starting materials or by different methods could be made comparable by applying the appropriate corrections.

METHODS

BLOOD SAMPLES Blood was collected from an antecubital vein by means of a plastic disposable syringe (not heparinized), introduced directly into plastic $96 \times 15 \mathrm{~mm}$. stoppered tubes (Stayne Laboratories Ltd.), heparinized as described by Fenton and Williams (1968), and cooled to $0^{\circ} \mathrm{C}$. in an ice-water bath. The ammonium content of whole blood was determined immediately. Plasma was separated within $30 \mathrm{~min}$. by centrifugation at $0^{\circ} \mathrm{C}$. If the $\mathrm{N}$ plasma samples were not to be subjected immediately to microdiffusion or ion exchange, they were kept frozen at $-10^{\circ} \mathrm{C}$. for not longer than 24 hours.

PLASMA AMMONIUM DETERMINATION AFTER ION-EXCHANGE A 'column blank' ( $2 \mathrm{ml}$. of deionized water taken through $\Phi$ the whole analysis) and a 'column recovery' $(2 \mathrm{ml}$. of a standard $\left(\mathrm{NH}_{4}\right)_{2} \mathrm{SO}_{4}$ solution containing $100 \mu \mathrm{g}$. of ${ }^{\circ}$ $\mathrm{NH}^{+}{ }_{4}-\mathrm{N}$ per $100 \mathrm{ml}$.) were run with each batch of determinations. A calibration curve was constructed for $\mathbb{D}$ each batch, using standard solutions composed of $4 \mathrm{ml}$. क्ष of $4 \mathrm{M}-\mathrm{NaCl}$ and $4 \mathrm{ml}$. of an $\mathrm{NH}^{+}{ }_{4}$ standard, to which 
alkaline phenol reagent and hypochlorite were added in the usual way. The ammonium standards used corresponded to plasma ammonium levels of 50,100 , and $200 \mu \mathrm{g}$. of $\mathrm{NH}_{4}^{+}-\mathrm{N}$ per $100 \mathrm{ml}$. respectively. Distilled water from a Manesty still was deionized before use by passage through a column of Amberlite MB - 1 resin. The method of determination (Fenton and Williams, 1968) was modified from the original description (Fenton, 1962). Instead of the nylon net diaphragm in the ion exchange columns we used a pledget of cottonwool, which had been previously treated for half an hour with $0.35 \mathrm{~N}-\mathrm{NaOCl}$ then washed thoroughly with water and stored in $4 \mathrm{M}-\mathrm{NaCl}$. The pledgets reduced the rate of fluid flow sufficiently and we did not fit hypodermic needles to the columns. The ion-exchange method was not used for $\mathrm{NH}^{+}{ }_{4}$ determinations on whole blood.

PLASMA AMMONIUM DETERMINATION BY MICRODIFFUSION Microdiffusion was carried out in $30 \mathrm{ml}$. glass Universal containers, as described by Seligson and Hirahara (1957), except that a stainless steel rod was not used as a stirrer. The rubber bungs, in which the glass rods were mounted for microdiffusion, were stored over concentrated $\mathrm{H}_{2} \mathrm{SO}_{4}$. The diffused ammonium was dissolved from the glass rod and estimated spectrophotometrically by the method of Brown, Duda, Korkes, and Handler (1957).

\section{RESULTS AND DISCUSSION}

Plasma ammonium levels were measured in nine subjects who were either healthy or had no evidence of liver or respiratory disease. Since it appeared that the size of the difference between whole blood ammonium and plasma ammonium was not consistent, whole blood ammonium was not determined in the remaining five patients. Instead, the recovery of ammonium from plasma by both methods was measured by carrying out determinations on a mixture of plasma and a $10 \mu \mathrm{g} . / \mathrm{ml}$. ammonium sulphate standard in the proportions $9: 1$. Thus sufficient ammonium was added to the plasma to increase its ammonium level by $100 \mu \mathrm{g}$. of ammonium nitrogen per $100 \mathrm{ml}$. Allowance was made for the dilution of the plasma samples in calculating the recoveries of ammonium.

The results are presented in Table $\mathbf{I}$.

Recoveries by the ion-exchange method are adequate and consistent, as was found previously (Acland and Strong, 1965). Recoveries by the microdiffusion method are inconsistent and unsatisfactory.
TABLE I

AMMONIUM LEVELS IN WHOLE BLOOD AND PLASMA DETERMINED BY MICRODIFFUSION AND ION EXCHANGE

\begin{tabular}{|c|c|c|c|c|c|c|c|}
\hline \multirow{3}{*}{\multicolumn{2}{|c|}{$\begin{array}{l}\text { Sex and } \\
\text { Age of } \\
\text { Subject }\end{array}$}} & \multirow{3}{*}{$\begin{array}{l}\text { Clinical } \\
\text { State }\end{array}$} & \multicolumn{5}{|c|}{ Ammonium Level $\left(\mu g\right.$. of $\mathrm{NH}^{+}-\mathrm{N} / 100 \mathrm{ml}$. } \\
\hline & & & \multicolumn{2}{|c|}{$\begin{array}{l}\text { Plasma (Ion } \\
\text { Exchange) }\end{array}$} & \multicolumn{2}{|c|}{$\begin{array}{l}\text { Plasma (Micro- } \\
\text { diffusion) }\end{array}$} & \multirow{2}{*}{$\begin{array}{l}\text { Whole } \\
\text { Blood } \\
\text { (micro- } \\
\text { diffu- } \\
\text { sion) } \\
\end{array}$} \\
\hline & & & $\begin{array}{l}\text { Un- } \\
\text { treated }\end{array}$ & $\begin{array}{l}\text { Re- } \\
\text { covery } \\
\text { of } \\
100 \mu \mathrm{g} . / \\
100 \mathrm{ml} \text {. }\end{array}$ & $\begin{array}{l}\text { Un- } \\
\text { treated }\end{array}$ & $\begin{array}{l}\text { Re- } \\
\text { covery } \\
\text { of } \\
100 \mu \mathrm{g} . / \\
100 \mathrm{ml} \text {. }\end{array}$ & \\
\hline \multirow{4}{*}{$\begin{array}{l}0 \\
0 \\
0 \\
0 \\
+\end{array}$} & 29 & Normal & 33 & - & 42 & 一 & 100 \\
\hline & 39 & Hypertensive & 28 & - & 25 & - & 227 \\
\hline & 22 & Normal & 36 & - & 66 & - & 86 \\
\hline & 15 & $\begin{array}{l}\text { Atrial septal } \\
\text { defect (pre- }\end{array}$ & & & & & \\
\hline \multirow{6}{*}{$\begin{array}{l}\text { } \\
+ \\
+ \\
+ \\
0 \\
0 \\
0\end{array}$} & & operative) & 23 & - & 46 & 一 & 53 \\
\hline & 60 & Hypertensive & 30 & 93 & 56 & 97 & - \\
\hline & 32 & ? Thyrotoxic & 20 & 96 & 55 & 81 & - \\
\hline & 61 & Hypertensive & 44 & 94 & 93 & 85 & - \\
\hline & 42 & ? Hypothyroid & 44 & 94 & 101 & 65 & - \\
\hline & 21 & $\begin{array}{l}\text { Atopic eczem } \\
\text { on steroids }\end{array}$ & 46 & 95 & 32 & 144 & - \\
\hline
\end{tabular}

Since the ammonium levels in whole blood and plasma, as determined by microdiffusion, do not appear to bear a constant relation either to each other or to the plasma ammonium level determined by ion-exchange, it is not possible to adjust the result of a determination by microdiffusion to correspond to the value which would be obtained by ion exchange. In our hands, the microdiffusion method has proved to be valueless, whereas the ion exchange method has been satisfactory.

We wish to thank Dr. A. Jordan for suggesting this investigation, Dr. J. C. B. Fenton for advice, and Miss Xena Hinchcliffe, Department of Surgery, University of Sheffield, for details of the microdiffusion analysis.

\section{REFERENCES}

Acland, J. D., and Strong, R. (1965). Lancet, 2, 345.

$\longrightarrow,-$ (1966). Ibid., 1, 100.

Bessman, A. N., and Evans, J. M. (1955). Amer. Heart J., 50, 715.

Brown, R. H., Duda, G. D., Korkes, S., and Handler, P. (1957). Arch. Biochem., 66, 301.

Conn, H. O (1960). J. Lab. clin. Med., 55, 855.

Dienst, S. G. (1961). Ibid., 58, 149.

Fenton, J. C. B. (1962). Clin. chim. Acta, 7, 163.

and Williams, A. H. (1968). J. clin. Path.,

Humoller, F. L., Barak, A. J., and Holthaus, J. M. (1964). Clin. Chem., $10,589$.

Seligson, D., and Hirahara, K. (1957). J. Lab. clin. Med., 49, 962.

, and Seligson, H. (1951). Ibid., 38, 324. 